\title{
REGRESI ROBUST ESTIMASI-M DENGAN PEMBOBOT ANDREW, PEMBOBOT RAMSAY DAN PEMBOBOT WELSCH MENGGUNAKAN SOFTWARE R
}

\author{
Aulia Desy Deria ${ }^{1}$, Abdul Hoyyi ${ }^{2}$, Mustafid ${ }^{3}$ \\ ${ }^{1,2,3}$ Departemen Statistika FSM Universitas Diponegoro \\ hoyyistat@gmail.com
}

\begin{abstract}
Robust regression is one of the regression methods that robust from effect of outliers. For the regression with the parameter estimation used Ordinary Least Squares (OLS), outliers can caused assumption violation, so the estimator obtained became bias and inefficient. As a solution, robust regression M-estimation with Andrew, Ramsay and Welsch weight function can be used to overcome the presence of outliers. The aim of this study was to develop a model for case study of poverty in Central Java 2017 influenced by the number of unemployment, population, school participation rate, Human Development Index (HDI), and inflation. The result of estimation using OLS show that there is violation of heteroskedasticity caused by the presence outliers. Applied robust regression to case study proves robust regression can solve outliers and improve parameter estimation. The best robust regression model is robust regression M-estimation with Andrew weight function. The influence value of predictor variables to poverty is $92,7714 \%$ and MSE value is 370,8817 .
\end{abstract}

Keywords: Outliers, Robust Regression, M-Estimator, Andrew, Ramsay, Welsch

\section{PENDAHULUAN}

Kemiskinan masih menjadi musuh terbesar bangsa Indonesia. Menurut BPS (2018), penduduk yang memiliki pengeluaran per kapita setiap bulannya dibawah garis kemiskinan, maka digolongkan sebagai penduduk miskin. Faktor-faktor yang diduga mempengaruhi kemiskinan di Jawa Tengah adalah pengangguran terbuka, jumlah penduduk, pendidikan, Indeks Pembangunan Manusia (IPM), dan inflasi.

Dari hasil studi awal penelitian menggunakan regresi linier berganda dengan estimasi parameter Metode Kuadrat Terkecil (MKT), diketahui pada data tentang kemiskinan terjadi pelanggaran asumsi heteroskedastisitas. Terjadinya heteroskedastisitas dalam model regresi kadangkala diikuti dengan munculnya beberapa pencilan dalam data. Menurut Sembiring (2003), adanya pencilan dalam data dapat mengakibatkan estimasi koefisien regresi yang diperoleh tidak tepat. Menurut Draper dan Smith (1992) penghapusan begitu saja terhadap data pencilan bukanlah langkah yang bijaksana. Adakalanya pencilan memberikan informasi yang tidak bisa diberikan oleh titik data lainnya.

Metode yang dapat digunakan untuk menganalisis data mengandung pencilan adalah regresi robust. Regresi robust terdiri dari 5 metode estimasi, yaitu M-estimator, Least Median Square (LMS)-estimator, Least Trimmed Square (LTS)-estimator, S-estimator, dan MM-estimator (Chen, 2002). Estimasi-M merupakan estimasi yang sering digunakan dan dapat dianalisis dengan mudah secara teoritis maupun komputer. Penelitian ini membahas analisis data kemiskinan tiap kabupaten/kota di Jawa Tengah menggunakan regresi robust M-estimator dengan menggunakan fungsi pembobot Andrew, pembobot Ramsay dan pembobot Welsch. Dari hasil analisis, kemudian akan dilakukan penentuan pemodelan regresi robust terbaik. Software yang digunakan untuk menganalisis penelitian ini adalah software $R$. 


\section{TINJAUAN PUSTAKA}

\subsection{Kemiskinan}

Kemiskinan secara umum dapat diartikan sebagai kondisi individu yang tidak mampu memenuhi kebutuhan hidup dasarnya secara layak. Menurut BPS (2018), penduduk yang memiliki pengeluaran per kapita setiap bulannya dibawah garis kemiskinan, maka digolongkan sebagai penduduk miskin.

\subsection{Faktor-Faktor yang Mempengaruhi Kemiskinan}

\subsubsection{Pengangguran}

Menurut Sukirno (2001), pengangguran merupakan seseorang yang telah masuk dalam golongan angkatan kerja, yang secara aktif sedang mencari pekerjaan pada suatu tingkat upah tertentu, tetapi tidak dapat memperoleh pekerjaan yang diinginkan.

\subsubsection{Jumlah Penduduk}

Menurut BPS (2018), penduduk merupakan semua orang yang berdomisili di wilayah teritorial Indonesia selama 6 (enam) bulan atau lebih dan atau mereka yang berdomisili kurang dari 6 (enam) bulan tetapi bertujuan untuk menetap.

\subsubsection{Pendidikan}

Angka Partisipasi Sekolah (APS) pada penduduk umur 16-18 tahun digunakan untuk mewakili variabel pendidikan. Menurut BPS (2018), APS merupakan proporsi dari semua anak yang masih sekolah pada suatu kelompok umur tertentu terhadap penduduk dengan kelompok umur yang sesuai.

\subsubsection{Indeks Pembangunan Manusia}

Menurut BPS (2018), Indeks Pembangunan Manusia (IPM) menjelaskan bagaimana penduduk dapat mengakses hasil pembangunan dalam memperoleh pendapatan, kesehatan, pendidikan dan sebagainya. IPM dibentuk oleh 3 (tiga) dimensi dasar, yaitu umur panjang serta hidup sehat, pengetahuan dan standar hidup layak.

\subsubsection{Inflasi}

Secara umum, inflasi dapat diartikan sebagai meningkatnya harga-harga secara umum dan terus-menerus.

\subsection{Analisis Regresi Linier}

\subsubsection{Regresi Linier Berganda}

Menurut Montgomery dan Peck (2012), Model regresi berganda dinyatakan dalam bentuk persamaan :

$$
y_{i}=\beta_{0}+\beta_{1} x_{i 1}+\beta_{2} x_{i 2}+\cdots+\beta_{k} x_{i k}+\varepsilon_{i}
$$

Jika ditulis dalam bentuk matriks, persamaan (1) dapat ditulis sebagai berikut :

$$
\begin{gathered}
\boldsymbol{y}=\boldsymbol{X} \boldsymbol{\beta}+\boldsymbol{\varepsilon} \\
\mathbf{y}=\left[\begin{array}{c}
\mathrm{y}_{1} \\
y_{2} \\
\vdots \\
y_{\mathrm{n}}
\end{array}\right] \quad ; \boldsymbol{X}=\left[\begin{array}{ccccc}
1 & x_{11} & x_{12} & \cdots & x_{1 k} \\
1 & x_{21} & x_{22} & \cdots & x_{2 k} \\
\vdots & \vdots & \vdots & \ddots & \vdots \\
1 & x_{n 1} & x_{n 2} & \cdots & x_{n k}
\end{array}\right] \quad ; \quad \boldsymbol{\beta}=\left[\begin{array}{c}
\beta_{0} \\
\beta_{1} \\
\vdots \\
\beta_{k}
\end{array}\right] \quad ; \quad \boldsymbol{\varepsilon}=\left[\begin{array}{c}
\varepsilon_{1} \\
\varepsilon_{2} \\
\vdots \\
\varepsilon_{\mathrm{n}}
\end{array}\right]
\end{gathered}
$$




\subsubsection{Estimasi Parameter Model Regresi Linier Berganda}

Metode yang digunakan untuk mengestimasi parameter model regresi adalah dengan meminimumkan jumlah kuadrat residual atau yang sering dikenal dengan Metode Kuadrat Terkecil (MKT) (Gujarati, 1997).

$$
J=\sum_{i=1}^{n} \varepsilon_{i}^{2}=\varepsilon^{\prime} \varepsilon=(y-X \beta)^{\prime}(y-X \beta)
$$

Untuk mendapatkan estimator kuadrat terkecil $(\widehat{\boldsymbol{\beta}})$ yang meminimumkan $\boldsymbol{J}$ disyaratkan bahwa $\left.\frac{\partial J}{\partial \boldsymbol{\beta}}\right|_{\boldsymbol{\beta}=\widehat{\boldsymbol{\beta}}}=0$. Turunan pertama dari $\boldsymbol{J}$ terhadap $\widehat{\boldsymbol{\beta}}$ adalah :

$$
\left.\frac{\partial J}{\partial \boldsymbol{\beta}}\right|_{\boldsymbol{\beta}=\widehat{\boldsymbol{\beta}}}=-2 \boldsymbol{X}^{\prime} \boldsymbol{y}+2 \boldsymbol{X}^{\prime} \boldsymbol{X} \widehat{\boldsymbol{\beta}}
$$

karena, $\left.\frac{\partial \boldsymbol{L}}{\partial \boldsymbol{\beta}}\right|_{\boldsymbol{\beta}=\widehat{\boldsymbol{\beta}}}=0$, maka

$$
\begin{aligned}
-2 X^{\prime} \boldsymbol{y}+2 X^{\prime} \boldsymbol{X} \widehat{\boldsymbol{\beta}} & =0 \\
\widehat{\boldsymbol{\beta}} & =\left(X^{\prime} \boldsymbol{X}\right)^{-1} \boldsymbol{X}^{\prime} \boldsymbol{y}
\end{aligned}
$$

\subsubsection{Uji Hipotesis dalam Regresi Linier Berganda}

\section{a. Uji F}

Uji signifikansi regresi digunakan untuk menguji apakah ada hubungan linier antara variabel respon $y$ dan variabel prediktor $x_{1}, x_{2}, \ldots, x_{k}$ secara bersama-sama (Montgomery dan Runger, 2003). Berikut langkah-langkahnya :

1. Hipotesis

$$
\begin{aligned}
& \mathrm{H}_{0}: \beta_{1}=\beta_{2}=\ldots=\beta_{\mathrm{k}}=0 \\
& \mathrm{H}_{1}: \text { terdapat } \beta_{\mathrm{j}} \neq 0, \text { dengan } \mathrm{j}=1,2, \ldots, \mathrm{k}
\end{aligned}
$$

2. Statistik uji

$$
F_{\text {hitung }}=\frac{S S_{R} / k}{S S_{E} /(n-k-1)}=\frac{\mathrm{MSR}}{\mathrm{MSE}}
$$

3. Kriteria uji

$$
\mathrm{H}_{0} \text { ditolak jika } F_{\text {hitung }}>F_{(\alpha, k, n-k-1)} \text { atau } p \text {-value }<\alpha
$$

\section{b. Uji Koefisien Regresi secara Individual (Uji t)}

Uji koefisien regresi secara individual digunakan untuk menguji ada tidaknya pengaruh yang signifikan antara masing - masing variabel prediktor terhadap model regresi linier. Menurut Montgomery dan Runger (2003), berikut langkah-langkah pengujiannya :

1. Hipotesis

$$
\begin{aligned}
& \mathrm{H}_{0}: \beta_{\mathrm{j}}=0 \\
& \mathrm{H}_{1}: \beta_{\mathrm{j}} \neq 0
\end{aligned}
$$

2. Statistik uji

$$
t_{\text {hitung }}=\frac{\widehat{\beta}_{j}}{\operatorname{Se}\left(\widehat{\beta}_{j}\right)} ; \text { dengan } \operatorname{Se}\left(\hat{\beta}_{j}\right)=\sqrt{\operatorname{var}\left(\hat{\beta}_{j}\right)}
$$

3. Kriteria uji

$$
\mathrm{H}_{0} \text { ditolak jika }\left|t_{\text {hitung }}\right|>t_{(\alpha / 2, n-k-1)} \text { atau } p \text {-value }<\alpha
$$

\subsubsection{Goodness Of Fit (Ukuran Kecocokan Model)}

\section{a. $\quad$ Koefisien Determinasi yang disesuaikan (Adjusted $\boldsymbol{R}^{2}$ )}

Menurut Ghozali (2011), koefisien determinasi $\left(R^{2}\right)$ merupakan alat untuk mengukur seberapa jauh kemampuan model dalam menerangkan variasi variabel respon. 


$$
R^{2}{ }_{A d j, k}=1-\frac{S S_{E} /(n-k-1)}{S S_{T} /(n-1)}
$$

b. MSE (Mean Square Error)

Menurut Montgomery dan Peck (2012), dalam analisis regresi rumus MSE adalah

$$
\mathrm{MSE}=\frac{S S_{E}}{n-k-1}
$$

\subsubsection{Uji Asumsi dalam Regresi Linier Berganda}

a. Uji Normalitas

Uji normalitas digunakan untuk mengetahui apakah residual dalam model regresi berdistribusi normal atau tidak. Gujarati (1997) menjelaskan bahwa pada regresi linear klasik diasumsikan bahwa tiap $\varepsilon_{i}$ didistribusikan normal dengan $\varepsilon_{i} \sim N\left(0, \sigma^{2}\right)$. Salah satu uji formal yang dapat digunakan untuk menguji asumsi normalitas adalah uji statistik Kolmogorov-Smirnov.

$$
D=\sup _{e}\left|F_{0}(e)-S(e)\right|
$$

\section{b. Multikolinieritas}

Menurut Montgomery dan Peck (2012), multikolinearitas terjadi karena terdapat korelasi yang cukup tinggi di antara variabel independen. Salah satu cara untuk mengukur besar multikolinearitas adalah menggunakan Variance Inflation Factor (VIF) yang didefinisikan sebagai berikut :

$$
V I F_{j}=\frac{1}{\left(1-R_{j}^{2}\right)}, \mathrm{j}=1,2, \ldots, \mathrm{k}
$$

Nilai VIF >10 menunjukkan multikolinearitas yang kuat (Montgomery dan Peck, 1992).

\section{c. Uji Autokorelasi}

Pada konteks regresi, model regresi linear klasik mengasumsikan bahwa autokorelasi seperti itu tidak terdapat dalam error $\varepsilon_{i}$ (Gujarati, 1997). Lambang non-autokorelasi adalah

$$
E\left(\varepsilon_{i} \varepsilon_{j}\right)=0 \quad i \neq j
$$

Secara sederhana dapat dikatakan model klasik mengasumsikan bahwa error yang berhubungan dengan pengamatan tidak dipengaruhi oleh error yang berhubungan dengan pengamatan lain yang manapun. Salah satu cara yang dapat digunakan untuk mendeteksi autokorelasi adalah dengan uji Durbin Watson.

$$
d=\frac{\sum_{i=2}^{i=n}\left(e_{i}-e_{i-1}\right)^{2}}{\sum_{i=1}^{i=n} e_{i}^{2}}
$$

\section{d. Uji Heteroskedastisitas}

Menurut Ghozali (2011) uji heteroskedastisitas bertujuan untuk menguji apakah dalam model regresi terjadi ketidaksamaan varian dari residual satu pengamatan ke pengamatan yang lain. Lambang homoskedastisitas : $E\left(\varepsilon_{i}^{2}\right)=\sigma^{2} \quad i=1,2, \ldots, n$

Heteroskedastisitas dapat diperiksa dengan menggunakan uji Glejser. Uji Glejser dilakukan dengan meregresikan nilai absolut residual $\left|e_{i}\right|$ terhadap variabel-variabel prediktor lainnya (Ghozali, 2011).

$$
\left|e_{i}\right|=\beta_{0}+\beta_{1} x_{i 1}+\beta_{2} x_{i 2}+\cdots+\beta_{k} x_{i k}+v
$$

\subsection{Pencilan}

Montgomery dan Peck (2012) menyatakan bahwa pencilan adalah titik-titik data yang tidak setipe dengan titik data yang lainnya. Salah satu metode yang dapat digunakan 
untuk mendeteksi pencilan adalah DFFITS (Difference in Fit Standardized). Rumus DFFITS $_{i}$ didefinisikan :

$$
\left(\text { DFFITS }_{i}\right)=t_{i}\left(\frac{h_{i i}}{1-h_{i i}}\right)^{\frac{1}{2}}
$$

dimana $t_{i}$ adalah studentized deleted residual untuk kasus ke- $i$ dengan rumus:

$$
t_{i}=e_{i} \sqrt{\frac{n-p-1}{S S_{E}\left(1-h_{i i}\right)-e_{i}^{2}}}
$$

Suatu data disebut pencilan jika nilai $\mid$ DFFITS $\mid>1$ untuk gugus data yang berukuran kecil sampai sedang dan nilai $|D F F I T S|>2 \sqrt{p / n}$ untuk gugus data yang berukuran besar, dengan $p=k+1$, dan $\mathrm{n}$ adalah banyaknya observasi (Neter, 1997).

\subsection{Regresi Robust M-Estimator}

Regresi robust merupakan metode yang digunakan untuk mengatasi masalah dari metode kuadrat terkecil yang disebabkan oleh data yang terkontaminasi oleh pencilan. Menurut Chen (2002), regresi robust memiliki lima metode estimasi yaitu M-estimator, LMS-estimator, LTS-estimator, S-estimator dan MM-estimator. Namun pada penelitian ini hanya digunakan M-estimator.

Menurut Draper dan Smith (1998), M-estimator meminimumkan fungsi obyektif :

$$
\min _{\beta} \sum_{i=1}^{n} \rho\left(u_{i}\right)=\min _{\beta} \sum_{i=1}^{n} \rho\left(\frac{e_{i}}{s}\right)=\min _{\beta} \sum_{i=1}^{n} \rho\left(\frac{y_{i}-\sum_{j=0}^{k} x_{i j} \beta_{j}}{s}\right)
$$

dimana $s$ adalah skala estimasi robust. Estimasi $s$ yang digunakan adalah:

dan $u_{i}=\frac{e_{i}}{s}$

$$
s=\frac{M A D}{0,6745}=\frac{\text { median } \mid e_{i}-\text { median }\left(e_{i}\right) \mid}{0,6745}
$$

Untuk meminimumkan persamaan (15), akan digunakan turunan parsial pertama fungsi $\rho$ terhadap $\beta_{j}(j=0,1, \ldots, k)$ sama dengan 0 , sehingga diperoleh :

$$
\sum_{i=1}^{n} x_{i j} \psi\left(\frac{y_{i}-\sum_{j=0}^{k} x_{i j} \beta_{j}}{s}\right)=0, \quad j=0,1, \ldots, k
$$

Draper dan Smith (1998) memberikan solusi dengan mendefinisikan fungsi pembobot :

$$
w\left(u_{i}\right)=\frac{\psi\left(\frac{y_{i}-\sum_{j=0}^{k} x_{i j} \beta_{j}}{s}\right)}{\left(\frac{y_{i}-\sum_{j=0}^{k} x_{i j} \beta_{j}}{s}\right)}
$$

dan $w_{i}=w\left(u_{i}\right)$. Kemudian estimasi persamaan (17) dapat ditulis:

$$
\sum_{i=1}^{n} x_{i j} w_{i}\left(y_{i}-\sum_{j=0}^{k} x_{i j} \beta_{j}\right)=0 \quad, j=0,1, \ldots, k
$$

Persamaan (19) diselesaikan dengan Iteratively Reweighted Least Square (IRLS). Pada notasi matrik, persamaan (19) dapat ditulis:

$$
\widehat{\boldsymbol{\beta}}_{\boldsymbol{j}}=\left(\boldsymbol{X}^{\prime} \boldsymbol{W} \boldsymbol{X}\right)^{-\mathbf{1}} \boldsymbol{X}^{\prime} \boldsymbol{W} \mathbf{y}
$$

Iterasi akan berhenti jika $\widehat{\boldsymbol{\beta}}_{\boldsymbol{j}}$ konvergen yaitu selisih nilai $\widehat{\boldsymbol{\beta}}_{\boldsymbol{j}}^{(\boldsymbol{m}+\mathbf{1})}$ dan $\widehat{\boldsymbol{\beta}}_{\boldsymbol{j}}^{(\boldsymbol{m})}$ mendekati 0 .

\subsection{Fungsi Obyektif}

Fungsi yang digunakan untuk mencari fungsi pembobot pada regresi robust adalah fungsi obyektif (Fox, 2002). Fungsi obyektif yang diturunkan terhadap $u_{i}$ akan menghasilkan suatu fungsi yang disebut sebagai fungsi pengaruh $\left(\psi\left(u_{i}\right)\right)$. Fungsi pengaruh yang dibagi dengan $u_{i}$ akan menghasilkan fungsi pembobot yang digunakan dalam perhitungan regresi robust. 
Tabel 1. Fungsi Obyektif dan Fungsi Pembobot untuk Estimasi Kuadrat Terkecil, Andrew, Ramsay dan Welsch

\begin{tabular}{|c|c|c|c|}
\hline Pembobot & Fungsi Obyektif & Fungsi Pembobot & Interval \\
\hline $\begin{array}{l}\text { Kuadrat } \\
\text { Terkecil }\end{array}$ & $\rho\left(u_{i}\right)=\frac{1}{2} u_{i}^{2}$ & $w\left(u_{i}\right)=1$ & $\left|u_{i}\right|<\infty$ \\
\hline Andrew & $\left(c_{1}\left(1-\cos \left(\frac{u_{i}}{c_{1}}\right)\right)\right.$ & $\left(\sin \left(\frac{u_{i}}{c_{1}}\right)\right.$ & $\left|u_{i}\right| \leq c_{1} \pi$ \\
\hline & $\rho\left(u_{i}\right)=\{$ & $w\left(u_{i}\right)=\{$ & $\left|u_{i}\right|>c_{1} \pi$ \\
\hline Ramsay & $\rho\left(u_{i}\right)=\frac{1-\left(\exp \left(-c_{2}\left|u_{i}\right|\right)\right)\left(1+c_{2}\left|u_{i}\right|\right)}{\left(c_{2}\right)^{2}}$ & $w\left(u_{i}\right)=\exp \left(-c_{2}\left|u_{i}\right|\right)$ & $\left|u_{i}\right|<\infty$ \\
\hline Welsch & $\rho\left(u_{i}\right)=\frac{c_{3}}{2}\left[1-\exp \left(-\left(\frac{u_{i}}{c_{3}}\right)^{2}\right)\right]$ & $w\left(u_{i}\right)=\exp \left(-\left(\frac{u_{i}}{c_{3}}\right)^{2}\right)$ & $\left|u_{i}\right|<\infty$ \\
\hline
\end{tabular}

Dimana nilai $c$ pada pembobot Andrew, pembobot Ramsay dan pembobot Welsch disebut tunning constant. Menurut Montgomery dan Peck (2012), tunning constant untuk pembobot Andrew adalah $c_{1}=1,339$, untuk pembobot Ramsay adalah $c_{2}=0,3$. Menurut Setiarini dan Listyani (2017), tunning constant untuk pembobot Welsch adalah $c_{3}=2,9846$.

\section{METODOLOGI PENELITIAN}

\subsection{Jenis dan Sumber Data}

Data yang digunakan dalam penelitian ini adalah data sekunder yang diperoleh dari Badan Pusat Statistik Provinsi Jawa Tengah melalui publikasi Jawa Tengah Dalam Angka 2018. Data yang terdapat dalam penelitian ini adalah data jumlah penduduk miskin, jumlah pengangguran terbuka, jumlah penduduk, Angka Partisipasi Sekolah (APS) untuk umur 1618 tahun, Indeks Pembangunan Manusia (IPM), dan inflasi setiap kabupaten/kota di Jawa Tengah tahun 2017.

\subsection{Variabel Penelitian}

Variabel yang digunakan dalam penelitian ini adalah:

$y \quad$ : Jumlah penduduk miskin

$x_{1}$ : Jumlah pengangguran terbuka

$x_{2}$ : Jumlah penduduk

$x_{3}$ : Angka Partisipasi Sekolah untuk umur 16-18 tahun

$x_{4}$ : Indeks Pembangunan Manusia

$x_{5}$ : Inflasi

\subsection{Langkah-Langkah Penelitian}

1. Mengumpulkan data dan menentukan variabel respon dan variabel prediktor.

2. Estimasi koefisien regresi menggunakan metode kuadrat terkecil.

3. Melakukan uji F dan uji koefisien regresi secara individual (uji t).

4. Menghitung koefisien determinasi yang disesuaikan (Adjusted $R^{2}$ ) dan MSE

5. Melakukan uji asumsi regresi liner berganda.

6. Melakukan pendeteksian pencilan dengan DFFITS $_{i}$.

7. Estimasi parameter dengan regresi robust M-Estimator

8. Melakukan uji F dan uji koefisien regresi robust secara individual (uji t).

9. Menentukan model regresi robust terbaik dan menganalisisnya. 


\section{HASIL DAN PEMBAHASAN}

\subsection{Regresi Linier Berganda}

Pada awal penelitian dilakukan analisis regresi linier berganda dengan estimasi parameter menggunakan Metode Kuadrat Terkecil.

\subsubsection{Estimasi Parameter Regresi}

Dari hasil output didapatkan model regresi linier berganda sebagai berikut:

$$
\begin{gathered}
\hat{y}=496,303500+0,000789 x_{1}+0,000089 x_{2}+1,708834 x_{3}- \\
9,041847 x_{4}+13,684860 x_{5}
\end{gathered}
$$

\subsubsection{Uji Hipotesis}

a. Uji F

1. Hipotesis

$\mathrm{H}_{0}: \beta_{1}=\beta_{2}=\beta_{3}=\beta_{4}=\beta_{5}=0$

$\mathrm{H}_{1}$ : terdapat $\beta_{\mathrm{j}} \neq 0, \mathrm{j}=1,2,3,4,5$

2. Taraf signifikansi

$\alpha=5 \%$

3. Statistik uji

$F_{\text {hitung }}=21,628240$

4. Kriteria uji

$\mathrm{H}_{0}$ ditolak jika $F_{\text {hitung }}>\left(F_{(5 \%, 5,29)}=2,545386\right)$

5. Keputusan

$\mathrm{H}_{0}$ ditolak karena nilai $F_{\text {hitung }}=21,628240>F_{(5 \%, 5,29)}=2,545386$

6. Kesimpulan

Pada taraf signifikansi 5\% paling sedikit ada satu variabel prediktor (jumlah pengangguran terbuka, jumlah penduduk, APS, IPM, dan inflasi) yang ada hubungan dengan variabel respon jumlah penduduk miskin secara bersamasama.

\section{b. Uji Koefisien Regresi secara Individual (Uji t)}

1. Hipotesis

$\mathrm{H}_{0}: \beta_{\mathrm{j}}=0$, dimana $\mathrm{j}=1,2,3,4,5$

$\mathrm{H}_{1}: \beta_{\mathrm{j}} \neq 0$, dimana $\mathrm{j}=1,2,3,4,5$

2. Taraf signifikansi

$\alpha=5 \%$

3. Statistik uji

Disajikan pada Tabel 2.

4. Kriteria uji

$\mathrm{H}_{0}$ ditolak jika $\left|t_{\text {hitung }}\right|>\left(t_{(2,5 \%, 135)}=1,97769\right)$ atau $p$-value $<\alpha(0,05)$

5. Keputusan

Tabel 2. Tabel Uji t Regresi Linier Berganda

\begin{tabular}{ccc}
\hline Variabel & $\left|\boldsymbol{t}_{\text {hitung }}\right|$ & Keputusan \\
\hline Jumlah Pengangguran Terbuka & 0,955834 & $\mathrm{H}_{0}$ diterima \\
Jumlah Penduduk & 2,904232 & $\mathrm{H}_{0}$ ditolak \\
APS & 1,845054 & $\mathrm{H}_{0}$ diterima \\
IPM & 4,469570 & $\mathrm{H}_{0}$ ditolak \\
Inflasi & 0,902133 & $\mathrm{H}_{0}$ diterima \\
\hline
\end{tabular}


6. Kesimpulan

Pada taraf signifikansi 5\% koefisien parameter variabel yang berpengaruh signifikan terhadap jumlah penduduk miskin $(y)$ adalah jumlah penduduk $\left(x_{2}\right)$ dan IPM $\left(x_{4}\right)$.

\subsubsection{Goodness Of Fit}

Dalam penelitian ini, uji kecocokan model yang digunakan adalah nilai koefisien determinasi yang disesuaikan dan nilai MSE. Diperoleh nilai koefisien determinasi yang disesuaikan sebagai berikut:

$$
R^{2}{ }_{\text {Adj }, k}=0,752080
$$

Hal ini mengindikasikan bahwa variasi total jumlah penduduk miskin $(y)$ sebesar 75,2080\% diterangkan oleh jumlah pengangguran terbuka $\left(x_{1}\right)$, jumlah penduduk $\left(x_{2}\right)$, APS $\left(x_{3}\right)$, IPM $\left(x_{4}\right)$, dan inflasi $\left(x_{5}\right)$, sedangkan sisanya $24,7920 \%$ dipengaruhi faktor yang lain.

Nilai MSE untuk regresi linier berganda menggunakan estimasi Metode Kuadrat Terkecil adalah sebagai berikut:

$\mathrm{MSE}=1366,756$

\subsubsection{Uji Asumsi dalam Regresi Linier Berganda}

\section{a. Uji Normalitas}

Uji Normalitas menggunakan uji Kolmogorov-Smirnov, sehingga diperoleh nilai $D$ sebesar 0,094193. Nilai $D$ tersebut lebih kecil dari $d_{\left(1-\frac{0,05}{2}\right)}=d_{(0,975)}=0,246$ maka dapat disimpulkan bahwa pada taraf signifikansi 5\% residual berdistribusi normal.

\section{b. Multikolinieritas}

Tabel 3. Nilai VIF

\begin{tabular}{ccc}
\hline Variabel & VIF & Keterangan \\
\hline Jumlah Pengangguran Terbuka & 4,266684 & VIF $<10$ \\
Jumlah Penduduk & 4,199171 & VIF $<10$ \\
APS & 2,054416 & VIF $<10$ \\
IPM & 2,043627 & VIF $<10$ \\
Inflasi & 1,164812 & VIF $<10$ \\
\hline
\end{tabular}

Berdasarkan Tabel 3 dapat disimpulkan bahwa pada taraf signifikansi 5\%, tidak terjadi multikolinieritas

\section{c. Uji Autokorelasi}

Uji Autokorelasi menggunakan uji Durbin Watson, sehingga diperoleh nilai $d$ sebesar 2,140334. Nilai $d$ tersebut berada diantara $d_{U}$ dan $4-d_{U}$ sebagai berikut:

$$
d_{U}(1,802900) \leq d(2,140334) \leq 4-d_{U}(2,197100)
$$

Pada taraf signifikansi 5\%, dapat disimpulkan bahwa tidak ada autokorelasi antar residual.

d. Uji Heteroskedastisitas

Tabel 4. Tabel Uji Glejser

\begin{tabular}{ccc}
\hline Variabel & $\left|\boldsymbol{t}_{\text {hitung }}\right|$ & Keputusan \\
\hline Jumlah Pengangguran Terbuka & 2,273737 & $\mathrm{H}_{0}$ ditolak \\
Jumlah Penduduk & 0,294061 & $\mathrm{H}_{0}$ diterima \\
APS & 0,742580 & $\mathrm{H}_{0}$ diterima \\
IPM & 1,464981 & $\mathrm{H}_{0}$ diterima \\
Inflasi & 1,005814 & $\mathrm{H}_{0}$ diterima \\
\hline
\end{tabular}

Berdasarkan Tabel 4 dapat disimpulksn bahwa pada taraf signifikansi 5\%, terjadi heteroskedastisitas. 


\subsection{Indentifikasi Pencilan}

Dalam kaitannya dengan analisis regresi, adanya pelanggaran asumsi heteroskedastisitas kadangkala diikuti dengan munculnya beberapa pencilan. Berikut cara untuk mengidentifikasi pencilan:

a. Metode Grafis Normal Q-Q Plot
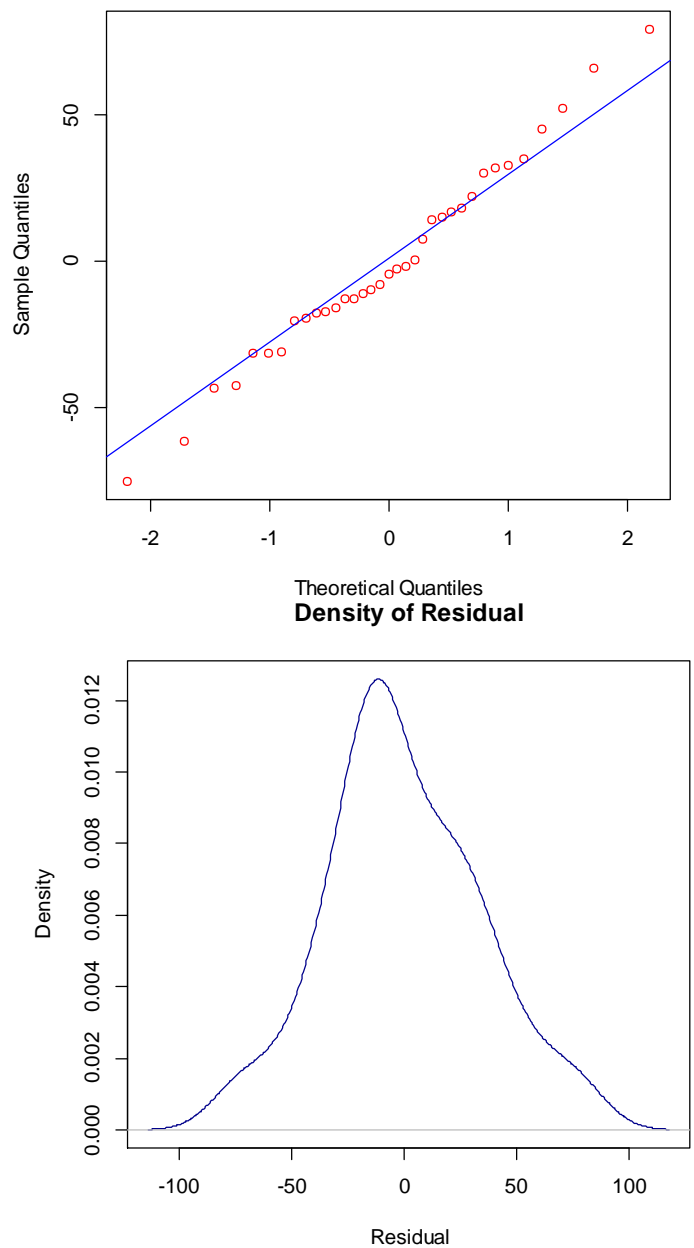
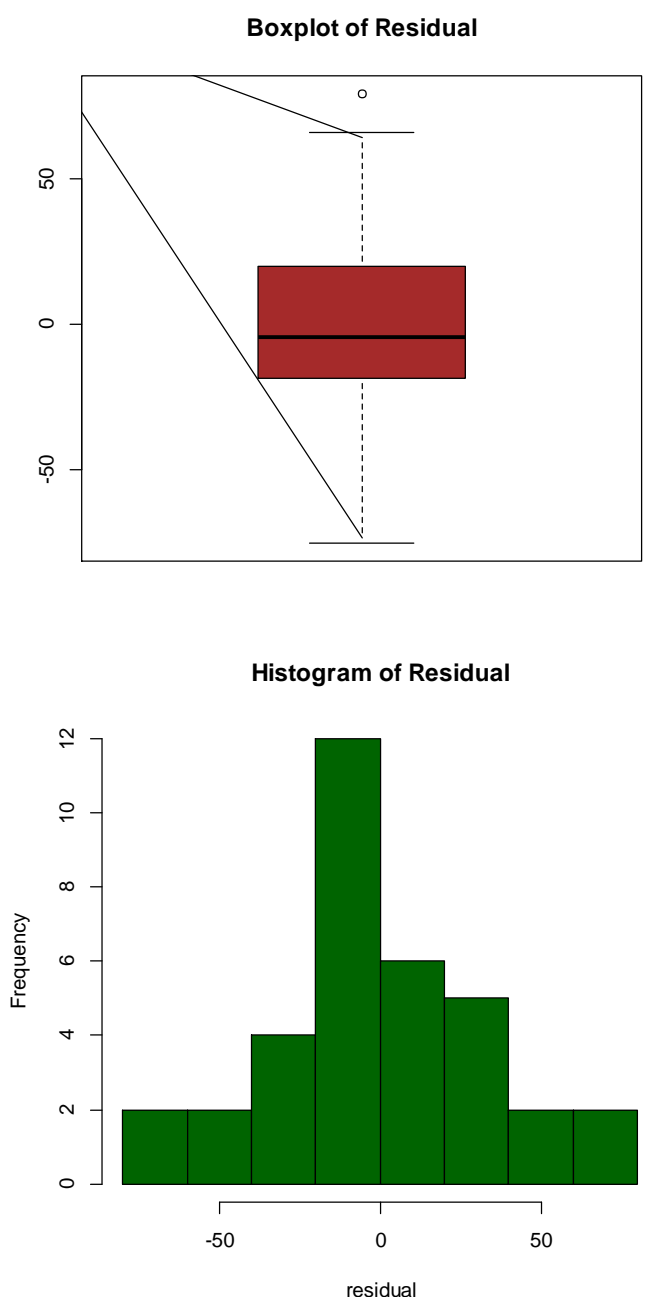

Gambar 1. Plot Residual dengan Estimasi Parameter MKT

Pada Gambar 1, secara visual terdapat pencilan dalam data residual. Untuk memastikan seberapa banyak pencilan dan data mana saja yang termasuk pencilan, maka dilakukan pendeteksian pencilan secara formal menggunakan DFFITS.

b. Identifikasi Pencilan dengan DFFITS

Jumlah data $(\mathrm{n})=35$ termasuk gugus data kecil atau sedang, maka batas suatu data dikatakan sebagai pencilan jika nilai $\mid$ DFFITS $\mid>1$. Dari hasil output, didapatkan bahwa ada sebanyak 4 pencilan terdeteksi, yaitu data ke-1 (Kota Semarang), data ke-16 (Kab. Banyumas), data ke-32 (Kab. Tegal), dan data ke-35 (Kab. Brebes).

\subsection{Regresi Robust}

\subsubsection{Regresi Robust M-Estimator (Pembobot Andrew)}

Model regresi robust M-estimator dengan pembobot Andrew yang didapatkan setelah proses 87 kali iterasi adalah sebagai berikut :

$$
\begin{gathered}
\hat{y}=341,6013+0,003069 x_{1}+0,000061 x_{2}+1,064543 x_{3}- \\
5,089440 x_{4}-13,976840 x_{5}
\end{gathered}
$$




\subsubsection{Regresi Robust M-Estimator (Pembobot Ramsay)}

Model regresi robust M-estimator dengan pembobot Ramsay yang didapatkan setelah proses 23 kali iterasi adalah sebagai berikut :

$$
\begin{gathered}
\hat{y}=502,6822+0,001153 x_{1}+0,000080 x_{2}+1,676396 x_{3}- \\
8,809452 x_{4}+7,899445 x_{5}
\end{gathered}
$$

\subsubsection{Regresi Robust M-Estimator (Pembobot Welsch)}

Model regresi robust M-estimator dengan pembobot Welsch yang didapatkan setelah proses 30 kali iterasi adalah sebagai berikut :

$$
\begin{gathered}
\hat{y}=323,516900+0,002922 x_{1}+0,000065 x_{2}+1,143818 x_{3}-5,142116 x_{4}- \\
9,763728 x_{5}
\end{gathered}
$$

\subsection{Pemilihan Model Regresi Robust Terbaik}

Tabel 5. Tabel Pembanding Regresi (MKT) dan Regresi Robust M-Estimator

\begin{tabular}{cccc} 
& Adjusted $\boldsymbol{R}^{\mathbf{2}}$ & MSE & $\begin{array}{c}\text { Variabel yang } \\
\text { Signifikan }\end{array}$ \\
\hline Pembobot Kuadrat Terkecil & 0,752080 & 1366,7560 & $x_{2}, x_{4}$ \\
Pembobot Andrew & 0,927714 & 370,8817 & $x_{1}, x_{2}, x_{4}$ \\
Pembobot Ramsay & 0,791707 & 817,1030 & $x_{2}, x_{3}, x_{4}$ \\
Pembobot Welsch & 0,914254 & 396,2673 & $x_{1}, x_{2}, x_{3}, x_{4}$ \\
\hline
\end{tabular}

Kriteria pemilihan model regresi robust terbaik yaitu mempunyai $R_{A d j, k}^{2}$ terbesar dan nilai MSE terkecil. Dari Tabel 5, disimpulkan bahwa model terbaik adalah M-estimator dengan pembobot Andrew.

$$
\begin{gathered}
\hat{y}=341,601300+0,003069 x_{1}+0,000061 x_{2}+1,064543 x_{3}- \\
5,089440 x_{4}-13,976840 x_{5}
\end{gathered}
$$

Dengan besar pengaruh jumlah pengangguran terbuka, jumlah penduduk, APS, IPM dan inflasi terhadap jumlah penduduk miskin di Jawa Tengah adalah 92,7714\% dan nilai MSE nya 370,8817 .

\section{KESIMPULAN}

Berdasarkan hasil penelitian diketahui bahwa melalui regresi dengan estimasi parameter menggunakan MKT terjadi pelanggaran asumsi heteroskedastisitas dan terdapat 4 pencilan, sehingga estimator yang dihasilkan bersifat bias dan tidak efisien. Regresi robust M-estimator dengan pembobot Andrew, pembobot Ramsay dan pembobot Welsch digunakan untuk mengatasi masalah tersebut. Kemudian dibandingkan berdasarkan nilai Adjusted $R$ square dan MSE, diperoleh model terbaik adalah pembobot Andrew :

$$
\begin{gathered}
\hat{y}=341,601300+0,003069 x_{1}+0,000061 x_{2}+1,064543 x_{3}- \\
5,089440 x_{4}-13,976840 x_{5}
\end{gathered}
$$

Regresi robust M-estimator dengan pembobot Andrew memberikan kesimpulan bahwa kemiskinan di Jawa Tengah dipengaruhi oleh jumlah pengangguran terbuka $\left(x_{1}\right)$, jumlah penduduk $\left(x_{2}\right), \operatorname{APS}\left(x_{3}\right), \operatorname{IPM}\left(x_{4}\right)$, dan inflasi $\left(x_{5}\right)$, sebesar $92,7714 \%$ dan nilai $M S E$ nya 370,8817 . Untuk variabel jumlah pengangguran terbuka, jumlah penduduk dan IPM berpengaruh signifikan terhadap kemiskinan, sedangkan APS dan inflasi tidak berpengaruh signifikan terhadap kemiskinan.

\section{DAFTAR PUSTAKA}

[BPS] Badan Pusat Statistik. 2018. Katalog Provinsi Jawa Tengah dalam Angka 2018. Jakarta : BPS. 
Chen, C. 2002. Robust Regression and Outlier Detection with The ROBUSTREG Procedure, paper 265-27. SAS Instutute Inc., Lary, NC.

Draper, N.R. dan Smith, H. 1992. Analisis Regresi Terapan. Edisi Kedua. Diterjemahkan oleh : Bambang Sumantri. Jakarta : Gramedia Pustaka Utama. Terjemahan dari : Applied Regression Analysis.

Fox, J. 2002. Robust Regression : Appendix to An R and S-Plus Companion to Applied Regression.

Ghozali, I. 2011. Ekonometrika Teori, Konsep dan Aplikasi dengan SPSS. Semarang : Badan Penerbit Universitas Diponegoro.

Gujarati, D.N. 1997. Ekonometri Dasar. Diterjemahkan oleh : Sumarno Zain. Jakarta : Erlangga. Terjemahan dari : Basic Econometrics.

Montgomery, D.C. dan Peck, E.A. 2012. Introduction To Linier Regression Analysis. Fifth Edition. New York : John Wiley and Sons, Inc.

Montgomery, D.C. dan Runger, G.C. 2003. Applied Statistics and Probability for Engineers. Third Edition. United States of America : John Wiley and Sons.

Neter, J., Wasserman, W., dan Kutner, M.H. 1988. Applied Linier Regression Model. USA : Richard D. Irwin. Inc.

Sembiring, R.K. 2003. Analisis Regresi. Edisi Kedua. Bandung : ITB.

Setiarini, Z., Listyani, E. 2017. Analisis Regresi Robust Estimasi-S Menggunakan Pembobot Welsch dan Tukey Bisquare. Jurnal Matematika. Vol. 6, No.1.

Sukirno, S. 2001. Pengantar Teori Makroekonomi. Jakarta : Raja Grafindo. 